\title{
Strategic Technology Management In Business: An Application In Automotive Industry
}

\author{
Ramazan Göral \\ Selcuk University, Konya,Turkey \\ Emali: trgora@@selcuk.edu.tr \\ Aziz Öztürk \\ Selcuk University, Konya,Turkey \\ Azizozturk42@hotmail.com
}

Doi:10.5901/ajis.2013.v2n9p739

\begin{abstract}
In this text, the level of the use of technology in the means of technological management and the relationship between technological management and the department that is responsible for this management activity shall be examined in a strategical point of view. In this respect, some inputs about the subject of this research had been obtained from automotive supply industry businesses by using the member database of TAYSAD. These inputs had been encoded one by one and then installed to SPSS program, which is used commonly for statistical evaluation of the research results. Thereafter, some charts had been created according to these hypothesis and the results in these charts had been analyzed and interpreted. After these evaluations, the meaningful relation between the level of the use of technology and strategical management of technology emerged. Besides, it is established that the level of the use of strategical technology management differs from business to business depending on departments that are responsible for management of technology. As a result, it is important to have managers who are in the strategical level and who have a background of technology education, for the use and management of technology for successfully integration of the process of strategical management and technology management.
\end{abstract}

Keywords: Management of Technology, Strategical Management of Technology

\section{Introduction}

Nowadays, being in control of technology also means being in control of competitive superiority. Putting New products on market has gained more importance than renovation of traditional products, since there is no more huge differences between research powers of giant firms. Thus, technology is increasing its importance gradually on being a strategical determinant factor (Esin, 1992).

As a result, management of technology is becoming as crucial as financial management or human resources management. Accepting technology as a functional talent requires developing strategies such the ones for finance and human resources.

While setting a strategy for technology, engaged questions such as choosing technological area to have an investment, the competition degree of technology, budget for development of technology, technology timing for New products and services, organizations for technological practice and development shall be answered (Bulgerman and Rosenbloom, 1998). strategies.

In this regard, management of technology is the integration and practice of work strategies and technology

In this case, management of technology should be the responsibility of the managers who are in strategical level and these managers should achieve the integration of business strategies and technology strategies while fulfilling their duty. This integration is named as Strategical Management of Technology within this text.

\section{Strategical Management of Technology}

Management of technology has started being popular after mid 1980s. It was under the influence of engineering based sciences in the first years. R\&D management happens to be the basis of this New area as the previous controller (Chanaron,Jolly, 1999). Later on (1987), National Research Council (NRC) brought forward the view that management of 
technology should be accepted as the common point of two scientific disciplines which used to be accepted as irrelevant concepts. These two disciplines are stated as; management talents and technical talents. This view is based on the idea that some management methods are needed to manage technological assets (NRC, 1987).

After that, Dankbaar has brought New meanings to management of technology. According to him, all technological harmony and orientation and R\&D and technology acquisition should be aimed at in a business' management activities and these Technologies shuld be used for manufacturing New products and services (Dankbaar, 1993).

Badawy's management of technology definition, integration and practice of work strategies and technology strategies (Badawy, 1998), has contributed to expanding of the traditional definitions. Badawy states that such integration is essential when the coordination of R\&D, manufacturing and other activities are taken into consideration.

However, approaches on technology management express the need for a systematic management of technology from a strategical and operational perspective lately (Linn and others, 2000). In this respect, management of technology is a process that includes developing technological talents, planning the practice, canalizing, controlling and coordinating to shape and carry out the strategic and operational purposes of a business.

Today, an area including manufacturing process technologies, process, tools and techniques for New production developments, marketing techniques, management of R\&D activities, management of innovation, international trade politics, intellectual property rights, industrial design, transfer of technology, management of information Technologies, internet strategy, environment and sustainable manufacturing and entrepreneurship should be focused on New product developing process on a corporate level, grounding on process of strategical management. This makes the integration of competition strategies and technology strategies obligatory. Total management understanding for this integration is named as Strategical Management of Technology.

\subsection{Process of Strategical Management of Technology}

Gregory has defined the process of strategical management of technology as a process that includes identification, selection, acquisition, operation and protection of technology (Gregory, 1995). Then, Ozgur (1999), Yuksel (2000) and Yildirim, Oner, Basoglu (2001) have added release (termination) step to this process (Oner and others, 2005).

Technology identification includes Technologies that companies do not possess at present but that can help companies for their development in the future.

Technology selection is determining which technology should the company support from among alternative Technologies. The decision has a big importance since it will identify the technology that will be invested on.

Technology transfer or acquisition means the strategies of technology acquisition from inside, outside or both.

Technology operation means using the technology that is acquired by developing or by purchase for own production and manufacturing process generally in order to have competition advantages. Company has acquired this technology fort his specific purpose already. However, company may generate an income by sharing its Technologies with other companies.

Technology protection has arised from necessity of protection of property rights and trading advantages of companies. It also means taking measures to protect database and property rights of companies and to prevent third parties from using companies' technologies. Generally, the most common measures to be taken are registration of patent I petty patent and design.

Termination of technology focuses on gaining New Technologies on time and reacting technological changes on time.

\section{Methodology}

\subsection{Method of Research and Sample}

In this research, cross sectionally, the data collection method that is based on transmitting Standard questionnaire form to sample group has been used because of the following reasons;

- Generalization of research results,

- Utilization from a huge sample group,

- Data collection about a scale of factors,

- Directing the same question group to every single answerer,

- Obtaining more sufficient statistics for analysis. 
While preparing the questions for the questionnaire form that is prepared in accordance with the research purposes, relevant literature and previous Works about the subject have been taken into consideration.

Addresses and mailing information of the companies' that are subject to this research were collected by using the member database of TAYSAD. On January, 2009, contacts with these companies were made by phone and the questionnaire forms were sent to their e-mail addresses. Comebacks were examined as of March, 2009; companies which did not make any comebacks were reached by receiving service from pollster companies and on June, 2009, salvational 103 questionnaire forms were collected. This number means a 40\% of comeback and this percentage is an acceptable percentage for examining. Questions in the questionnaire were encoded one by one and then installed to SPSS program. Thereafter, some charts were created according to these hypothesis and the results in these charts had been analyzed and interpreted.

\subsection{Hypothesis of The Research}

- H1. Companies that have a better use of technology also have better practise of strategical management of technology activities.

- H2. There is a relation between the departments that are responsible for management of technology and practice of strategical management of technology activities level.

\section{Results of The Research}

Statistical analysis of the data obtained as a result of this research shall be explained by charts and figures. These results shall be evaluated whether they are statistically meaningful and shall be examined whether they confirm the hypothesis.

\subsection{Introductory Information for Businesses}

\subsubsection{Size of a Business}

While specifying the size of a business, one of the most common quantitive criterias is the number of employees. Hence, the size of a business is specified according to its employees quantity. Business which has employees less than 100 are specified as small, business which has employees between 100-499 are specified as medium and business which has employees more than 500 are specified as big sized business.

When the businesses which took part in the research examined with regard to their employees' number, there are 41 small sized businesses (39,8\%), 48 medium sized businesses (46,6\%) and 14 big sized businesses $(13,6 \%)$.

\subsubsection{Sector of Manufacturing}

When Technologies and raw materials used in businesses work in automotive supply industry are examined, it is seen that they have enough manufacturing facilities not only for their own sector, but also for other sectors. For example, a member of Taysad, Egebant Zimpara Ve Polisaj Malz. San. Ve Tic. A.Ş. is the supplier of businesses which are active in vehicles industry such as Temsa, Mercedes-Benz Türk, Tofaş Fiat, Renault, Karsan, Toyota, Man, Türk Traktör Karsan, Hyundai, Isuzu, Honda, Bmc, Uzel; but it also makes productions for other firms such as Vestel, Indesit, Arçelik, Bsh, Thy, Koçtaş. According to the answers to the question in the questionnaire whether businesses use this facility show that $38(37 \%)$ of the firms which answered this question make production for both automotive sector and other sectors while $65(63 \%)$ of them make productions only for automotive sector.

\subsubsection{Capital Structure}

While $196(77,1 \%)$ of the members of TAYSAD are domestic invested; 58 (22,9\%) of them are foreign invested or have foreign investment partnership. On the other hand, $82(79,6 \%)$ of the firms which attended to this research are domestic invested, $12(11,7 \%)$ of them are foreign invested and $9(8,7 \%)$ of them are foreign investment partnerships. Considering these data, the percentage of foreign invested or foreign investment partnerships that attended to the research is apparently similar to the percentages of capital structures of the firms in sample group. Thus, it is possible to conclude that the firms attended to the questionnaire represent the total of the sample with regards to capital structure. 


\subsubsection{Manufacturing Method}

There are two different segments in automotive supply industry market that manufacturers can supply products. One of them is the original part manufacturer segment, called OEM. The other segment is the method of supplying supply industry parts to the showrooms intended for the customers instead of manufacturers, called Aftermarket.

$60(59,4 \%)$ of the companies which attended to the research are making productions for OEM while $15(14,9 \%)$ of them are making productions for Aftermarket. $26(25,7 \%)$ of the companies are making productions for both segments. In this case, $86(85,1 \%)$ of these companies are product suppliers of auto manufacturers and production line.

\subsubsection{Quality Certificate Status}

These companies were asked for their quality certificates, considering its importance in competition abilities in Turkish automotive supply industry.

2 of these companies stated that they are not intended to obtain any quality certificates. $24(23,3 \%)$ of them have ISO 9001 certificate, $2(1,9 \%)$ of them have ISO 14001 certificate, 35 (34\%) of them have both ISO 9001 and ISO 14001 certificates, $19(18,4 \%)$ of them have ISO-TS 16949 certificate and $21(20,4 \%)$ of them have different quality certificates. In this regard, it is possible to state that Turkish automative supply industry firms are conscious of the importance of quality certificates.

\subsubsection{Educational Background of Business Managers}

According to the researches, role of executive managers of a business is crucial in developing a successful technology strategy. Firms with a managers who have strong technological background pay more attention to technology while taking strategical decisions. Managers who do not have a strong technological background or who do not pay enough attention to technology face serious problems arising from their communication disorders with their technical team. In this regard, firms which have a use or management of technology should prefer executive managers with background of technological education (Oner and others, 2005).

Majority $(73-71 \%)$ of the managers of the firms that attended to the research have had engineering education. This is a positive fact for automotive supply industry firms that needs to have strong technological platform.

\subsection{Practices of Strategical Technology Management of Businesses}

Practises of Strategical Technology Management is formed by using the strategies of Industrial Organization Theory and Resource Based Theory together and connecting them with processes of technology management rather than accepting them as alternative choices.

A research has been made in order to understand whether level of technology usage of firms affects the efficiency of strategic technology management activities. (Chart-1)

Chart 1. Efficiency of Strategic Technology Management Process Activities in regards with Level of Technology Usage of Firms

\begin{tabular}{|c|c|c|c|c|c|c|}
\hline \multirow{3}{*}{$\begin{array}{c}\text { Strategic Technology } \\
\text { Management Process Activities }\end{array}$} & \multicolumn{4}{|c|}{ Level of Technology Usage of Firms } & \multirow{2}{*}{\multicolumn{2}{|c|}{ Mann-Whitney U Test }} \\
\hline & \multicolumn{2}{|c|}{ Low $(n=53)$} & \multicolumn{2}{|c|}{ High $(n=50)$} & & \\
\hline & Ort. & S.S. & Ort. & S.S. & $\mathbf{z}$ & $p$ \\
\hline Total Identification Process & 18,72 & 3,77 & 24,66 & 7,30 & $-5,709$ & $<, 001$ \\
\hline Total Selection Process & 27,98 & 4,92 & 31,56 & 3,10 & $-3,908$ & $<, 001$ \\
\hline Total Acqusition Process & 15,77 & 2,85 & 18,06 & 2,15 & $-4,231$ & $<, 001$ \\
\hline Total Operation Process & 27,32 & 5,33 & 31,60 & 3,48 & $-4,251$ & $<, 001$ \\
\hline Total Protection Process & 11,57 & 2,27 & 13,22 & 1,62 & $-3,794$ & $<, 001$ \\
\hline Total Termination Process & 28,32 & 4,17 & 31,28 & 3,90 & $-3,396$ & $<, 001$ \\
\hline General Total $^{*}$ & 149,2 & 22,60 & 173,6 & 17,09 & $-5,13$ & $<, 001$ \\
\hline
\end{tabular}

\footnotetext{
* Reliability coefficient of the scale is checked before the General Total. Cronbach alpha value of the scale is 0,96.
} 
According to the results in Chart-1, efficiency of the activities for each step of technology management process is higher in firms in which the level of technology usage is also higher. Results are statistically significant according to Mann Whitney $U$ test. This significancy of the results support Hypothesis Number 1: "efficiency of the activities for each step of technology management process is higher in firms in which the level of technology usage is also higher".

Tschirky (Tschirky, 1997) states that three levels of management play a role in technology management. These are stated as; Normative, Strategical and Operational Levels. Normative Level includes executive decision making bodies. Technology management is not directly subject to normative level but managers in this bodies should have technological education.

In strategical level, business strategies are cut into small purposes. Doing the right things and efficiency comes into prominence in this level. Decisions such as manufacturing Technologies to use within the business or purchasing them fall into this level.

In operational level, strategies are transferred to short-term activities. In this level, fundamental principles are doing the right thing and being productive. Deciding on which personal to choose for a R\&D Project or determining a financial resource are two of the examples of the decisions of this level.

Besides, when we have a look at management levels with regards to strategical management, we see management levels as Company (Corporate), Business (Strategic) and functional (Dincer, 1998).

Company level means a executive decision making mechanism as a whole in a company that has different businesses and different working groups.

Business level is relevant to the way of competition in a certain branch of Industry or product/market department and the activities to be done. This level focuses on resource allocation in business, comparative advantages and synergy since it deals more with competition problems.

Functional level is formed by decisions of functional departments within the business. It is more aimed at increasing productivity of used resources.

We can understand from the explanations that these two classifications made from different angles point at the same management levels. In other words, normative level (company) may be accepted as strategic level (business) and operational level (functional).

The chart (Chart-2) that shows "Relation of Technology Management Process and Top Management" emphasizes that technology management work is mainly a work of strategic level management (Yildirim, 2000).

Chart 2. Of Technology Management Process and Top Management

\begin{tabular}{|l|l|c|}
\hline \multicolumn{1}{|c|}{ TM Process } & \multicolumn{1}{|c|}{ Activity } & Management Level \\
\hline \multirow{4}{*}{$\begin{array}{l}\text { Technology } \\
\text { Determination }\end{array}$} & Selection of information resources & Strategic \\
\cline { 2 - 3 } & Combination of information about current and developed Technologies & Strategic \\
\cline { 2 - 3 } & $\begin{array}{l}\text { Analysis of environmental factors on a product, firm, market and national } \\
\text { basis while choosing from different technological alternatives }\end{array}$ & Strategic \\
\hline \multirow{4}{*}{$\begin{array}{l}\text { Technology } \\
\text { Selection }\end{array}$} & Determination of priorities and importance of certain Technologies & Strategic \\
\cline { 2 - 3 } & Benefit-cost analysis of alternatives of technology & Strategic \\
\cline { 2 - 3 } & $\begin{array}{l}\text { Evaluation of efficiency of the chosen Technologies by customers, } \\
\text { suppliers, processes and employees }\end{array}$ & Strategic \\
\hline \multirow{2}{*}{$\begin{array}{l}\text { Technology } \\
\text { Acquisition }\end{array}$} & Determination of resources for technology acquisition & Strategic \\
\cline { 2 - 3 } $\begin{array}{l}\text { Technology } \\
\text { Operation }\end{array}$ & Determination of technology acquisition methods & Strategic \\
\cline { 2 - 3 } $\begin{array}{l}\text { Technology } \\
\text { Protection }\end{array}$ & Adaptation of acquired Technologies within the organization & Strategic \\
\cline { 2 - 3 } & Converting technological value into Money & Operational \\
\hline
\end{tabular}

In this respect, possible relation between efficiency of technology management activities and department responsible for technology management in firms has been researched. Results are in Chart-3. 
Chart 3. Efficiency of Strategic Technology Management Process Activities According to Technology Management Department

\begin{tabular}{|c|c|c|c|c|c|c|c|c|}
\hline \multirow{3}{*}{$\begin{array}{c}\text { Strategic Technology } \\
\text { Management Process Activities }\end{array}$} & \multicolumn{6}{|c|}{ Department Responsible for Technology Management } & \multirow{2}{*}{\multicolumn{2}{|c|}{ Anova Test }} \\
\hline & \multicolumn{2}{|c|}{ Chiefdom ( $n=7)$} & \multicolumn{2}{|c|}{ Directorship $(n=39)$} & \multicolumn{2}{|c|}{ general } & & \\
\hline & Ort & S.S. & Ort & S.S. & Ort & S.S. & $\mathbf{F}$ & $p$ \\
\hline Total Determination Process & 23,57 & 10,01 & 20,69 & 8,93 & 21,87 & 3,17 & 0,739 & 0,48 \\
\hline Total Selection Process & 26,57 & 7,18 & 28,97 & 4,16 & 30,45 & 4,12 & 3,11 & $<, 05$ \\
\hline Total Acquisition Process & 15,57 & 3,10 & 16,08 & 2,69 & 17,51 & 2,62 & 4,075 & $<, 05$ \\
\hline Total Opration Process & 26,43 & 6,60 & 28,13 & 4,57 & 30,55 & 4,82 & 4,169 & $<, 05$ \\
\hline Total Protection Process & 11,00 & 2,58 & 11,56 & 1,97 & 13,02 & 1,94 & 7,689 & $<, 05$ \\
\hline Total Termination Process & 27,29 & 4,79 & 29,10 & 3,96 & 30,35 & 4,33 & 2,176 & 0,119 \\
\hline Total General & 154,7 & 39,9 & 154,0 & 20,93 & 165,8 & 21,56 & 3,277 & $<, 05$ \\
\hline
\end{tabular}

When we examine Chart-3, we understand that efficiency of selection process, acquisition process, operation process and protection process activities are higher in businesses in which activities are made in general directorate level and the results relevant to these options are statistically significant. These results support Hypothesis Number 2: "there is a relation between efficiency of technology management activities and department responsible for technology management".

\section{Conclusion}

The role of executive managers of a firm is crucial in developing a successful strategy of technology. Firms which have managers with technological background pays more attention to technology while taking strategic decisions. Managers who do not have a sufficient technological background and who do not take technology seriously have some problems with their technical teams arising from communicational disorders. In this respect, operation of technology and having strategic level managers with technological background in management are very important for successful integration of strategic management of firms and management processes.

\section{References}

Badawy,M.K.(1998).Technology Management Education: Alternatives Models, Colifornia Management Review, 40(4),94-115

Bulgerman, R.A.,Rosenbloom, R.S.,(1998). Design and Implementation of Technology Strategy: An Evolutionary Perspective, In Technology Management Handbook, CRC Press,1.

Chanaron,J.J.,ve Jolly, D.(1999). Technologicial Management, Eppending the Perspective of Management of Technology, IAMOT Conference, Cairo,Ehypt.

Dankbaar, B.(1993), Research and Technology Management in Enterprises: Insues for Community Policy, Overall Strategic Reviev, EUR, Brussels.

Dinçer, Ö.(1998). Stratejik Yönetim ve İşletme Politikası, Besinci Basım, Beta Basım Yayım, İstanbul.

Esin, A.(1992).Dünya'da Globalizasyon ve AT'nun Sanayi Politikası-Türkiye'ye Etkileri,I.K.V.,s.116.

Gregory, M. J.(1995).Technology Management: A Process Approach, Proceedings of the Institute of Mechanical Engineers.

Linn, R.,J.,Zhang,W.,Li, Z.(2000).An Intelligent management System For Technology Management, Computer and Industrial Engineering. s.397. www.elsevier.com/locate/dsw

National Research Council,.(1987). Management of Technology: The Hidden Competitive Advantage,Report of the Task Force on Management of Technology, National Academy of Press. Washington.

Öner, M.A., Badak, U.Ö.,Akçay, S. ve Özşarlak, Ş.(2005).Türkiye'de 12 Otomotiv Yan Sanayi Firmasının Teknoloji Süreçleri Yönetim Yetenekleri Profilleri, TAYSAD Dergisi Eki.24.s.3.

Tschirky, H.(1997).Bringin Technology into Management: The Call of Reality Going Beyond Industrial Management at ht ETH.s.243.

Yıldırım. O. U.(2000). Technology Processes Management Capability Profiles of Machine Manu facturers in Turkey. Yeditepe Üniversitesi.Yayınlanmamış Yükseklisans Tezi. s.83. 